\title{
GASTROESOPHAGEAL REFLUX IN CIRRHOTIC PATIENTS WITH ESOPHAGEAL VARICES WITHOUT ENDOSCOPIC TREATMENT
}

\author{
Rosana Bihari SCHECHTER ${ }^{1}$, Eponina Maria Oliveira LEMME${ }^{1}$, and Henrique Sérgio Moraes COELHO²
}

\begin{abstract}
Background - Portal hypertension in patients with liver cirrhosis causes manifestations such as esophageal varices, ascites and edema. Some studies have been conducted about the role of esophageal varices in the development of esophageal motor disorders and abnormal gastroesophageal reflux in these patients. Ascites could be a factor promoting gastroesophageal reflux and it has been questioned whether reflux would favor the rupture of varices. However there are a few studies using ambulatory esophageal $\mathrm{pH}$ recording in the evaluation of these patients. Aims - Evaluate gastroesophageal reflux by $\mathrm{pH}$ recording in cirrhotic patients with esophageal varices and possible predictors. Methods - Fifty one patients (28 men, 23 women, mean age of 54 years) with liver cirrhosis, diagnosed by clinical, laboratorial, image and histological findings were prospectively evaluated. All patients had esophageal varices confirmed by endoscopy and were submitted to a questionnaire about typical gastroesophageal reflux disease symptoms (heartburn and or acid regurgitation). $\mathrm{pH}$ recording was performed with the probe placed $5 \mathrm{~cm}$ above the superior lower esophageal sphincter limit, as determined by manometry. Abnormal reflux (\% total time with $\mathrm{pH}<4>4.5 \%$ ) was related to the size of varices, congestive gastropathy, ascites, severity of cirrhosis and typical gastroesophageal reflux disease symptoms. Results - The caliber of the varices was considered to be small in 30 patients (59\%), medium in $17(33 \%)$ and large in $4(8 \%), 21$ (41\%) congestive gastropathy. Ascites was observed in $17(33 \%), 32$ patients $(63 \%)$ were classified as Child-Pugh A, 17 (33\%) Child-Pugh B and 2 (4\%) Child-Pugh C. Twenty seven patients (53\%) presented with typical gastroesophageal reflux disease symptoms. Abnormal reflux at $\mathrm{pH}$ recording was found in 19 patients (37\%). One of them presented with erosive esophagitis at endoscopy. There was no relation between ascites, variceal size, congestive gastropathy and Child-Pugh score and abnormal reflux. There was a correlation between typical gastroesophageal reflux disease symptoms and abnormal reflux. Conclusions - Abnormal gastroesophageal reflux was found in $37 \%$ of the patients with hepatic cirrhosis and esophageal varices. Only typical gastroesophageal reflux disease symptoms predicted these findings.
\end{abstract}

HEADINGS - Gastroesophageal reflux. Liver cirrhosis. Esophageal and gastric varices.

\section{INTRODUCTION}

Gastroesophageal reflux disease (GERD) is a highly prevalent disorder, with $7 \%$ of a healthy population presenting heartburn daily ${ }^{(23,29)}$. GERD clinical symptoms can be typical or atypical ${ }^{20,38)}$. Only half of GERD patients present with esophageal erosions $\mathbf{s}^{(7,8,16,18)}$.

The prevalence of liver cirrhosis is also large, with high morbidity and mortality ${ }^{(1)}$. Portal hypertension is responsible for the development of esophageal and gastric varices $^{(36)}$. Varices are potential sources of bleeding, increasing the mortality risk of these patients. The mechanisms that underlie the rupture of esophageal and gastric varices must be studied.

In the last years, the role of esophageal varices (EV) as a factor for the development of esophageal motors disorders and abnormal gastroesophageal reflux (GER) in liver cirrhotic patients has been discussed ${ }^{(1,3,15,32)}$. It is doubtful whether these abnormalities can contribute to the bleeding of varices. Some studies demonstrate motors disorders in the esophageal body, a delay in esophageal clearance time $^{(12)}$ and abnormal gastroesophageal reflux ${ }^{(1)}$ in cirrhotic patients with $\mathrm{EV}^{(3,15,32)}$, as compared to cirrhotic patients without varices and a control group. These studies suggest that motor disorders would be caused by EV and not by cirrhosis.

Other studies suggest that ascites would be able to increase intra-gastric and intra-abdominal pressure $e^{(3,26,37)}$. However, there are few studies using ambulatory esophageal $\mathrm{pH}$ recording (pHR) in cirrhotic patients with $\mathrm{EV}$, with or without ascites ${ }^{(1,15,28)}$.

The aim of this study was to evaluate the prevalence of abnormal GER in cirrhotic patients with EV, without previous endoscopic treatment and its possible predicting factors.

Divisions of ${ }^{1}$ Gastroenterology and ${ }^{2 H e p a t o l o g y, ~ " C l e m e n t i n o ~ F r a g a ~ F i l h o " ~ U n i v e r s i t y ~ H o s p i t a l, ~ F e d e r a l ~ U n i v e r s i t y ~ o f ~ R i o ~ d e ~ J a n e i r o, ~ R J, ~ B r a z i l . ~}$

Correspondence: Dr. Rosana Bihari Schechter - Rua Raul Pompéia, 24 - apt.603 - Copacabana - 22080-000 - Rio de Janeiro, RJ, Brazil. E-mail: rsbihari@yahoo.com.br 


\section{METHODS}

\section{Patients}

From June 2000 to June 2002, patients with liver cirrhosis and EV non submitted to endoscopic treatment were prospectively evaluated. The patients came from the Liver Outpatient Clinic of "Clementino Fraga Filho" University Hospital, Federal University of Rio de Janeiro, RJ, Brazil. We excluded patients with systemic disease related to esophageal motors disorders and/or gastroesophageal reflux disease (progressive systemic sclerosis, diabetes mellitus, neuromusculars disorders), alcohol abusers until 6 months before this study and chronic users of drugs that influence esophageal motility (calcium channel blockers, teophyline, nitrates).

All patients were evaluated by the same physician (RBS), according a protocol for classifying cirrhosis etiology, Child-Pugh score $^{(34)}$ ascites and GERD typical symptoms, such as heartburn and/or acid regurgitation.

The diagnosis of liver cirrhosis and its etiology was made by clinical, laboratory, image and histopathological methods. The latter included the presence of parenchymal nodules separated by fibrous septa, differences in liver cell size and appearance between one area and another, fragmentation of the biopsy specimen, altered architecture and vascular relationships without septa formation ${ }^{(2)}$. Ascites was classified as small, moderate or large according to clinical criteria ${ }^{(36)}$.

\section{METHODS}

\section{Upper gastrointestinal endoscopy}

All patients performed upper gastrointestinal endoscopy, in the standard fashion, in order to evaluate EV, classified as small (variceal diameter less than $3 \mathrm{~mm}$ ), medium (diameter from 3 to $6 \mathrm{~mm}$ ) or large (diameter greater than $6 \mathrm{~mm})^{(31)}$. Gastric varices and/or congestive gastropathy associated ${ }^{(24)}$ were also described. Esophagitis if present was classified according to SAVARY and MILLER ${ }^{(35)}$ grade I - isolated erosions; grade II - confluent but not circumferencial erosions; grade III - confluent and circumferencial erosions; grade IV - ulcers, stenosis. Hiatal hernia was considered as present if the gastroesophageal junction was at least $2 \mathrm{~cm}$ above the diaphragmatic impression ${ }^{(27)}$.

\section{Esophageal manometry}

Esophageal manometry (EMN) was performed to situate the superior limit of the lower esophageal sphincter (LES). Manometric studies used an eight lumen, 4,5 $\mathrm{mm}$ diameter polyvinyl catheter, continuously perfused with distilled water at $0,6 \mathrm{~mL} / \mathrm{min}$ by a low-compliance pneumohydraulic capillary infusion system (Biomedics - California, EUA) or solid-state intraluminal transducers (Kronisberg). The technique had already been described elsewhere ${ }^{(22)}$. Briefly, the probe was passed by one of the nostrils until the stomach. LES studies used slow pulltrough technique, with catheter tractions with $1.0 \mathrm{~cm}$ increments. The superior limit of the lower esophageal sphincter was the place (in centimeters) immediately before the register of the esophageal body pattern, when the tracing drops below the gastric baseline pressure.

\section{4-hour pH ambulatory recording}

The technique had been described elsewhere ${ }^{(21)}$. Briefly, it was carried out with a portable digital system (MK III Synectis) composed of a catheter with an antimony electrode and external reference electrode, placed $5 \mathrm{~cm}$ above superior limit of LES as defined by manometry. The recording of an esophageal $\mathrm{pH}$ of less than 4 for at least $15 \mathrm{sec}$ was considered to be a reflux episode. The patient had a normal activity and was under a normal diet, avoiding citric fruits and soft drinks. Proton pump inhibitor if in use, were discontinued at least 7-10 days prior to the exam, H2 blockers $48-72 \mathrm{~h}$ and prokinetics agents $24 \mathrm{~h}$. Abnormal reflux was defined ${ }^{(17)}$ when the percentage of the total time of $\mathrm{pH}$ below 4 was greater than $4.5 \%$, or the percentage of the upright time in which $\mathrm{pH}$ below 4 was grater than $7.0 \%$ or the percentage of supine time when $\mathrm{pH}$ was lower than 4 was greater than 2.5 . In upright reflux, only upright time percentage was abnormal, supine reflux if just supine time percentage was abnormal and in both positions if both time percentages were abnormal $^{(6)}$.

\section{Data analysis}

Abnormal reflux was related to the following variables: presence of ascites and severe ascites, typical GERD symptoms, Child-Pugh score (grouping Child-Pugh in two groups, A and $\mathrm{B}+\mathrm{C}$ ), congestive gastropathy, esophageal variceal size (also considering only two groups, small size varices and medium + large size varices).

To evaluate the meaning of these differences we used Chisquare test.

In abnormal $\mathrm{pHR}$ tests, for comparisons of $\%$ total time (TT), \% upright time (UT), \% supine time (ST) between the groups with ascites/severe ascites and without ascites, we employed Mann-Whitney test, as well to compare the group with and without GERD symptoms. A $P$ value $<0.05$ was used for significance.

\section{RESULTS}

Fifty one patients met the inclusion criteria, 28 male (55\%) and 23 female $(45 \%)$, mean age $54 \pm 10.5$ years $(17-77)$.

The diagnosis of hepatic cirrhosis was done by histopathological criteria in 47 (92\%) of the patients. Its etiology included C virus in 31 patients $(60, \%)$, alcohol in $8(16 \%)$, B virus in $3(6 \%)$, primary biliar cirrhosis in $2(4 \%)$, hemochromatosis in $1(2 \%)$, auto-imune em $1(2 \%)$, non-alcoholic steatohepatitis in $1(2 \%)$ and cryptogenic in 4 patients $(8 \%)$.

The patients were classified as Child $\mathrm{A}-32$ patients $(63 \%)$, Child $\mathrm{B}-17$ patients $(33 \%)$ and Child $\mathrm{C}-2$ patients (4\%).

Ascites was present in 17 (33\%) and absent in $34(67 \%)$. In the patients with ascites, eight $(47 \%)$ presented small ascites, three (18\%) with moderate ascites and six $(35 \%)$ with severe ascites.

Typical symptoms of gastroesophageal reflux disease were present in 27 patients $(53 \%)$. 
The EV presented small size in 30 patients $(59 \%)$, medium size in 17 patients $(33 \%)$ and large size varices in $4(8 \%)$.

Gastric varices were present in 4 patients $(8 \%)$ and congestive gastropathy in 21 patients $(41 \%)$.

Erosive esophagitis (Savary-Miller grade I) was present in one patient $(2 \%)$ and there was no hiatal hernia.

The $\mathrm{pH}$ recording demonstrated abnormal reflux in 19 patients (37\%), 04 (21\%) just in upright position, 07 (37\%) in supine position and $08(42 \%)$ in both positions.

\section{Relation between variables}

\section{Ascites and abnormal reflux}

Ascites was present in 17 patients. Seven of them (41\%) presented with an abnormal pHR. In the 34 patients without ascites, $12(35 \%)$ had abnormal pHR. There was no relation between ascites presence and abnormal reflux $(P=0.682)$ (Table 1$)$.

TABLE 1. pHR versus ascites $(n=51)$

\begin{tabular}{lccc}
\hline & Abnormal pHR & Normal pHR & Total \\
\hline With ascites $\mathrm{n}=17$ & $07(41 \%)$ & $10(59 \%)$ & $17(100 \%)$ \\
Without ascites $\mathrm{n}=34$ & $12(35 \%)$ & $22(65 \%)$ & $34(100 \%)$ \\
Total $\mathrm{n}=51$ & $19(37 \%)$ & $32(63 \%)$ & $51(100 \%)$ \\
\hline
\end{tabular}

$P$ value $=0.682$

$\mathrm{pHR}=$ ambulatory esophageal $\mathrm{pH}$ recording

\section{Severe ascites and abnormal reflux}

From 17 patients with ascites, $6(35 \%)$ presented with severe ascites and 4 of these $(67 \%)$ presented an abnormal pHR. There was no relation between severe ascites and abnormal reflux, when compared to patients without ascites $(P=0.148)$.

\section{Typical symptoms and abnormal reflux}

In 27 patients with typical reflux symptoms, 14 (52\%) presented with abnormal pHR and $13(48 \%)$ with normal pHR. In 24 patients without typical reflux symptoms, 5 (21\%) had abnormal $\mathrm{pHR}$. There was a significant relation between typical reflux symptoms and abnormal reflux $(P=0.022) *$ (Table 2$)$.

TABLE 2. Abnormal pHR versus typical gastroesophageal reflux symptoms $(\mathrm{n}=51)$

\begin{tabular}{lccc}
\hline & Abnormal pHR & Normal pHR & Total \\
\hline With symptoms $(\mathrm{n}=27)$ & $14(52 \%)$ & $13(48 \%)$ & $27(100 \%)$ \\
Without symptoms $(\mathrm{n}=24)$ & $05(21 \%)$ & $19(79 \%)$ & $24(100 \%)$ \\
Total $\mathrm{n}=51$ & $19(37 \%)$ & $32(63 \%)$ & $51(100 \%)$ \\
\hline
\end{tabular}

$P$ value $=0.022$ *

$\mathrm{pHR}=$ ambulatory esophageal $\mathrm{pH}$ recording

\section{Child-Pugh score and abnormal reflux}

In 32 patients Child $\mathrm{A}, 11(34 \%)$ presented with abnormal pHR and $21(66 \%)$ had normal pHR.

From 19 patients with Child B + C score, $8(42 \%)$ had an abnormal $\mathrm{pHR}$ and $11(58 \%)$ had it normal. There was no relation between Child-Pugh score and abnormal reflux $(P=0.581)$.

\section{Congestive gastropathy and abnormal reflux}

In 21 patients with congestive gastropathy, 6 (29\%) presented abnormal pHR and 15 (71\%) normal pHR and in 30 patients without congestive gastropathy, 13 (43\%) had abnormal pHR and $17(57 \%)$ had not. There was no relation between congestive gastropathy and abnormal reflux $(P=0.283)$.

\section{EV size and abnormal reflux}

In 30 patients with small size varices, $13(43 \%)$ had abnormal pHR and 17 (57\%), pHR was normal.

In 21 patients with medium + large size varices, $6(29 \%)$ had an abnormal pHR and $15(71 \%)$ had it normal. There was no relation between varices size and abnormal reflux $(P=0.283)$.

\section{DISCUSSION}

Gastroesophageal reflux in cirrhotic patients with EV has been studied for many years. Older studies based on necropsy paid great importance to esophageal acid reflux as a factor for the rupture and bleeding of $\mathrm{EV}^{(5,39)}$. They believed that extensive mucosal erosion of the varices would suffice to cause perforation. Other studies reinforced these initial findings, as they showed a higher prevalence of esophagitis ${ }^{(33)}$ and acid reflux ${ }^{(37)}$ in cirrhotic patients with non-bleeding varices and a lower LES pressure in cirrhotic patients with massive ascites ${ }^{(30,37)}$.

However, later studies weakened this hypothesis, because they could not demonstrate either lower LES pressure ${ }^{(9,25)}$ nor a higher incidence of abnormal GER in this group of patients ${ }^{(10,25)}$. Since then, the importance of GER in EV bleeding diminished.

In the last decades, as variceal bleeding continued to be a severe complication ${ }^{(10)}$, new risk factors for rupture have been evaluated. Esophageal acid reflux was again studied and its prevalence among cirrhotic patients with EV has been studied. This renewed interest possibly came from the greater diffusion of pHmetry recording, as well as from the existence of patients with reflux without esophagitis ${ }^{(1,15,27)}$.

In our study, abnormal reflux was demonstrated in $37 \%$ of patients, these $80 \%$ had abnormal reflux during the night, when esophageal defenses are lower, with reduction of saliva production, swallowing and esophageal clearance ${ }^{(7)}$. Increase in contact time between acid and varices could lead to the eventual erosion of the mucosa and the consequent bleeding.

It is possible to question, if this prevalence of abnormal reflux is related to the presence of cirrhosis with $\mathrm{EV}$ or if it is just a coincident finding in this population sub-group. AHMED et al. ${ }^{(1)}$ studied by pHmetry, 25 cirrhotic and 30 GERD patients. Abnormal reflux was observed in $64 \%$ of the cirrhotic patients and in $70 \%$ of the GERD patients without liver disease. Among the cirrhotic patients with GERD, $81 \%$ presented EV and no relation was found concerning variceal size. These authors suggest that GERD is common in cirrhotics with EV, independent of caliber or GERD symptoms. In our study we did not find any correlation between abnormal GER, variceal caliber.

Ascites in cirrhotic patients is another factor potencially important for the development of GERD and some studies have considered this hypothesis ${ }^{(3,28,37)}$. Although the LES pressure 
protective function against reflux remains intact during the resting state, a functional loss could occur during abrupt raises of intra-abdominal pressure and/or during transitory relaxations of $\operatorname{LES}^{(3,30,39)}$. In our study, we could not find any relation between ascites itself and abnormal GER.

Typical symptoms of GERD, heartburn and/or acid regurgitation, were observed in $53 \%$ of patients, its presence being correlated to abnormal GER. As described in the literature, typical reflux symptoms, despite their low sensitivity, have high specificity ${ }^{(19)}$. Therefore, in face of typical symptoms, GERD should be suspected. However, we could not find a correlation between the presence or absence of symptoms and the intensity of reflux.

It was also not possible to make a correlation of symptoms with gastrointestinal endoscopy findings because only one patient had erosive esophagitis and he presented only with occasional heartburn. This confirms the literature in that it is not possible to preview endoscopic findings by the intensity or frequency of symptoms ${ }^{(16)}$.

In our study, with exception of typical GERD symptoms, there was no correlation between any other studied factor and the presence of abnormal GER.

We question what would be the cause of the high prevalence of GERD found in this study and in the few others that employed pHR as their research tool ${ }^{(1,28)}$. Studies have demonstrated that no changes in LES pressure occur in patients with EV,

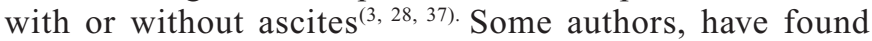
esophageal motor disorders in cirrhotic patients with $\mathrm{EV}$, as well as a decrease in amplitude of the peristaltic waves, in opposition to that observed in cirrhotic without varices and an asymptomatic control group ${ }^{(32)}$. These changes associated to $\mathrm{EV}$, independent of the cirrhosis itself, could delay esophageal clearance and increase contact time between acid and mucosa, promoting injury ${ }^{(32)}$.

Other comments can be advanced. It has currently been established the importance of nitrous oxide (NO), a potent vasodilator, in the exacerbation of portal hypertension in liver cirrhosis. This substance can be found in large amounts in the systemic circulation of cirrhotic patients ${ }^{(4)}$. NO excessive systemic action has risen investigative interest.

There are studies about the effect of NO in the esophageal peristalsis and LES. NO has been shown to decrease amplitude of distal esophageal peristaltic waves, as well as the velocity of the peristaltic contractions in the proximal esophagus ${ }^{(13)}$. It is true to question if the excess of $\mathrm{NO}$ in cirrhotic patients could exacerbate these manifestations, prolonging esophageal clearance, increasing contact time between acid and the esophageal mucosa. Besides, NO has an important role in the development of transitory relaxations in LES secondary to gastric fundus distension, which are followed by reflux episodes ${ }^{(13)}$. LES transitory relaxations is the commonest mechanism of GER, either in healthy volunteers $(70 \%-100 \%)$ as in GERD patients $(63 \%-74 \%)^{(19,26)}$.

More recently, a study with healthy volunteers ${ }^{(14)}$ showed that the use of substances that inhibit NO synthesis (1-arginine N monomethyl) significantly diminish the frequency of transitory relaxations in LES, after solid food intake, as well as decrease the number of total reflux episodes. However, gastric emptying time interval, LES pressure and/or the relaxation of LES secondary to deglutition are not affected.

These findings support the importance of NO, albeit not alone, in the activation of transitory relaxations in LES and the subsequent GER episodes. If NO synthesis inhibition can decrease the occurrence of transitory relaxations in the LES, then its excessive production could lead to an increase in the frequency of transitory relaxations and consequently in the total number of reflux episodes. In liver cirrhosis, as there is NO excess, could this be the causal factor for the development of an elevated prevalence of abnormal reflux? In this case, abnormal GER would occur independently of any associated factor such as EV and/or ascites.

Studies on the role of NO in VE cirrhotic patients with reflux are necessary to clarify this aspect.

\section{CONCLUSIONS}

Abnormal gastroesophageal reflux was found in $37 \%$ of cirrhotic patients with EV. There was correlation only between typical symptoms of gastroesophageal reflux disease and abnormal reflux. The questioning about typical reflux symptoms must be a part of the cirrhotic patients interrogatory. If present, a workup for abnormal reflux must be done or the patient should be empirically treated.

Long-term ambulatory follow-up of this group of patients is important, since, if the "erosive" theory holds true, patients with abnormal reflux could present a higher incidence of variceal bleeding. This, however, needs to be demonstrated.

\section{ACKNOWLEDGEMENTS}

This study received a grant from "José Bonifácio" University Foundation, Federal University of Rio de Janeiro, RJ. Thanks to Dr. Felix Zyngier, MD, for the manuscript review. 
Schechter RB, Lemme EMO, Coelho HSM. Prevalência do refluxo gastroesofágico em pacientes cirróticos com varizes de esôfago sem tratamento endoscópico. Arq Gastroenterol. 2007;44(2):145-50.

RESUMO - Racional - A hipertensão porta que acomete os pacientes com cirrose hepática é causa de varizes de esôfago, ascite e edema. Alguns estudos têm sido realizados para avaliar a importância das varizes de esôfago no desenvolvimento dos distúrbios motores esofagianos e do refluxo gastroesofágico anormal neste grupo de pacientes. A ascite pode ser um fator promotor de refluxo gastroesofágico e tem sido questionado se o refluxo anormal poderia favorecer a rotura das varizes de esôfago. Entretanto, são poucos os estudos que utilizam a pHmetria esofagiana prolongada ambulatorial na avaliação destes pacientes. Objetivos - Avaliar a presença de refluxo anormal a pHmetria esofagiana prolongada ambulatorial em pacientes cirróticos com varizes de esôfago e seus possíveis fatores preditivos. Métodos - Cinqüenta e um pacientes (28 homens, 23 mulheres, média de idade de 54 anos) com cirrose hepática diagnosticada por métodos clínicos, laboratoriais, de imagem e histopatológicos foram avaliados de forma prospectiva. Todos os pacientes apresentavam varizes de esôfago à endoscopia digestiva alta e foram submetidos a um questionário para avaliação da presença de sintomas típicos da doença do refluxo gastroesofágico (pirose e/ou regurgitação ácida). pHmetria esofagiana prolongada ambulatorial foi realizada posicionando-se o cateter $5 \mathrm{~cm}$ acima do limite superior do esfíncter esofagiano inferior, determinado previamente pela esofagomanometria. Refluxo anormal ( $\%$ tempo total com $\mathrm{pH}<4>4,5 \%$ ) foi relacionado com o tamanho das varizes, gastropatia congestiva, ascite, gravidade da cirrose e presença de sintomas típicos da doença do refluxo gastroesofágico. Resultados - O calibre das varizes foi considerado pequeno em 30 pacientes (59\%), médio em 17 (33\%) e grosso em 4 (8\%), 21 (41\%) gastropatia congestiva. Ascite foi observada em 17 (33\%); 32 pacientes (63\%) foram classificados com Child-Pugh A, 17 (33\%) Child-Pugh B e 2 (4\%) Child-Pugh C. Vinte e sete pacientes (53\%) apresentavam sintomas típicos da doença do refluxo gastroesofágico. Refluxo anormal a pHmetria esofagiana prolongada ambulatorial foi demonstrado em 19 pacientes (37\%). Apenas um deles apresentava esofagite erosiva à endoscopia digestiva alta. Não houve relação entre ascite, calibre das varizes, gastropatia congestiva e classificação de Child-Pugh com refluxo anormal. Houve correlação entre a presença dos sintomas típicos da doença do refluxo gastroesofágico e refluxo anormal. Conclusões - Refluxo anormal foi demonstrado em $37 \%$ dos pacientes com cirrose hepática e varizes de esôfago. Apenas os sintomas típicos foram preditores de refluxo anormal.

DESCRITORES - Refluxo gastroesofágico. Cirrose hepática. Varizes esofágicas e gástricas. 


\section{REFERENCES}

1. Ahmed AM, Al Karawi MA, Shariq S, Mohamed AE. Frequency of gastroesophagea reflux in patients with liver cirrhosis. Hepatogastroenterology. 1993;40:478-80.

2. Anthony PP, Ishak KG, Nayak NC, Poulsen HE, Scheuer PJ, Sobin LH. The morphology of cirrhosis. Recommendations on definition, nomenclature and classification by a working group sponsored by the World Health Organization. J Clin Pathol. 1978;31:395-414.

3. Bhatia SJ, Narawane NM, Shalia KK, Mistry FP, Sheth MD, Abraham P, Dherai AJ. Effect of tense ascites on esophageal body motility and lower esophageal sphincter pressure. Indian J Gastroenterol. 1999;18:635-7.

4. Cárdenas A, Ortega R, Ginés P. The hepatocirculatory syndrome in cirrhosis. In: Arroyo V, Bosch J, Bruix J, Ginés P, Navasa M, Rodés J, editors. Therapy in hepatology. Barcelona: Ars Medica; 2001;33-41.

5. Chiles NH, Baggenstoss AH, Butt HR, Olsen AM. Esophageal varices: comparative incidence of ulceration and spontaneous rupture as a cause of fatal hemorrhage. Gastroenterology. 1953;25:565-73.

6. De Meester TR, Wang CI, Wernly JA, Pellegrini CA, Little AG, Klementschitsch P, Bermudez G, Johnson LF, Skinner DB. Technique, indications and clinical use of 24 hours esophageal pH monitoring. J Thorac Cardiovasc Surg. 1980;79:656-70.

7. DeMeester TR, Johnson LF, Joseph GJ, Toscano MS, Hall AW, Skinner DB. Patterns of gastroesophageal reflux in health and disease. Ann Surg. 1976;184:459-70.

8. Dent J, Brun J, Frendrick AM, Fennerty MB, Janssens J, Kahrilas PJ, Lauritsen K, Reynolds JC, Shaw M, Talley NJ. An evidence based appraisal of reflux disease management. The Genval Workshop Report. Gut. 1998;44(Suppl 2):s1-s16.

9. Eckardt VF, Grace ND, Kantrowitz PA. Does lower esophageal sphincter incompetency contribute to esophageal bleeding? Gastroenterology. 1976;71:185-9.

10. Eckardt VF, Grace ND. Gastroesophageal reflux and bleeding esophageal varices. Gastroenterology. 1979;76:39-42.

11. Fitz JG. Approach to the patient with suspected liver disease. In: Friedman SL, McQuaid $\mathrm{KR}$, Grendell JH, editors. Current diagnosis and treatment in gastroenterology. 2nd ed. New York: Lange; 2002. p.521-35.

12. Ham HR, Urbain D. Esophageal transit of liquid in chronic alcoholism in patients with cirrhosis. Influence of esophageal varices. Clin Nucl Med. 1994;19:809-12.

13. Hirsch DP, Holloway RH, Tytgat GNJ, Boeckxstaens GEE. Involvement of nitric oxide in human transient lower esophageal sphincter relaxations and esophageal primary peristalsis. Gastroenterology. 1998;115:1374-80.

14. Hirsch DP, Tiel-Van Buul MM, Tytgat GNJ, Boeckxstaens GEE. Effect of L-NMMA on postprandial transient lower esophageal sphincter relaxations in healthy volunteers. Dig Dis Sci. 2000;45:2069-75.

15. Iwakiri K, Kobayashi M, Sesoko M, Nomura T. Gastroesophageal reflux and esophageal motility in patients with esophageal varices. Gastroenterol Jpn. 1993;28:477-82.

16. Johansson KE, Ask P, Boeryd B, Fransson SG, Tibbling L. Oesophagitis signs of reflux and gastric acid secretions in patients with symptoms of gastroesophageal reflux disease. Scand J Gastroenterol. 1986;21:837-47.

17. Johnson LF, De Meester TR. Twenty-four-hour $\mathrm{pH}$ monitoring of the distal esophagus. A quantitative measure of gastroesophageal reflux. Am J Gastroenterol. 1974;62:325-32.

18. Johnsson F, Joelsson B, Gudmunsson K, Greiff L. Symptoms and endoscopic findings in the diagnosis of gastroesophageal reflux disease. Scand J Gastroenterol. 1987;22:714-8.

19. Klauser AG, Schindlbeck NE, Muller-Lisser SA. Symptoms in gastroesophageal reflux disease. Lancet. 1990;335:205-8.

20. Klinkeberg-Knol E, Castell DO. Clinical spectrum and diagnosis of gastroesophageal reflux disease. In: Castell D, Richter JE, editors. The esophagus. 3rd ed. Philadelphia: Lippincott Williams \& Wilkins; 1999. p.375-80.
21. Lemme EMO, Almeida SM, Firman CMG, Pantoja JP, Nascimento FAP. pHmetria esofagiana prolongada - Avaliação de 170 exames. Arq Gastroenterol. 1997;34:71-7.

22. Lemme EMO, Domingues GR, Silva LFD, Grossi C, Pantoja JAS. Esofagomanometria computadorizada - resultados preliminares em voluntários adultos saudáveis. Gastroent Endosc 2001;20:29-35.

23. Locke GR, Talley NJ, Fett SL, Zinsmeister AR, Melton LJ. Prevalence and clinical spectrum of gastroesophageal reflux: a population based study in Olmested country, Minnesota. Gastroenterology. 1997;112:1448-56.

24. McCormack TT, Sims J, Eyre-Brook I, Kennedy H, Goepel J, Johnson AG, Triger DR Gastric lesions in portal hypertension: Inflamatory gastritis or congestive gastropathy? GUT 1985;26:1226-32.

25. McDougall BRD, Williams R. A controlled clinical trial of cimetidine in the recurrence of variceal hemorrhage: Implications about the pathogenesis of hemorrhage. Hepatology. 1983;3:69-73.

26. Mittal RK, McCallum RW. Characteristics and frequency of transient relaxations of the lower esophageal sphincter in patients with reflux esophagitis. Gastroenterology. 1988;95:593-9.

27. Moraes-Filho J, Cecconello I, Gama-Rodrigues J, Castro L, Henry MA, Meneghelli UG, Quigley E, Brazilian Consensus Group. Brazilian consensus on gastroesophageal reflux disease: proposals for assessment, classification and management. Am J Gastroenterol. 2002;97:241-8

28. Navarro-Rodriguez T, Hashimoto CL, Carrilho FJ, Strauss E, Laudanna AA, Moraes-Filho JP. Reduction of abdominal pressure in patients with ascites reduces gastroesophageal reflux. Dis Esophagus. 2003;16:77-82.

29. Nebel OT, Formês MF, Castell DO. Symptomatic gastroesophageal + reflux: incidence and precipiting factors. Dig Dis Sci. 1976;21:953-6.

30. Nebel OT. Lower esophageal sphincter function in cirrhosis. Dig Dis Sci. 1977;22:1101-5

31. Palmer ED, Brick IB. Correlation between the severity of esophageal varices in cirrhosis and their propensity toward hemorrhage. Esophageal varices and hemorrhage. Gastroenterology. 1956;30:85-90.

32. Passaretti S, Mazzotti G, de Franchis R, Cipolla M, Testoni PA, Tittobello A. Esophageal motility in cirrhotics with and without esophageal varices. Scand J Gastroenterol. 1989;24:334-8

33. Polish E, Sullivan BH. Esophagitis associated with hemorrhage from esophageal varices. Ann Intern Med. 1961;54:908-11.

34. Pugh RNH, Murray-Lyon IM, Dawson JL, Pietroni MC, Williams R. Transection of the esophagus for bleeding oesophageal varices. Br J Surg. 1973;60:646-9.

35. Savary M, Miller G. The esophagus. Handbook and atlas of endoscopy. Solothurn, Switzerland: Verlag Grassmann; 1978. p.135-42.

36. Schiano TD, Bodenheimer HC. Complications of chronic liver disease. In: Friedman SL, McQuaid KR, Grendell JH, editors. Current diagnosis and treatment in gastroenterology. 2nd ed. New York: Lange; 2002. p.639-63.

37. Simpson JA, Conn HO. Role of ascites in gastroesophageal reflux with comments on the pathogenesis of bleeding esophageal varices. Gastroenterology. 1968;55:17-25.

38. Traube M. The spectrum of the symptoms and presentations of gastroesophageal reflux disease. Gastroenterol Clin North Am. 1990;19:609-16.

39. Wagenknecht TW, Noble JF, Baronofsky ID. Nature of bleeding in esophageal varices Surgery. 1953;33:869-74. 